\title{
THE SOUTHEAST ASIAN SHOPHOUSE AS A MODEL FOR SUSTAINABLE URBAN ENVIRONMENTS
}

\author{
J. ARANHA \\ College of Architecture, Texas Tech University.
}

\begin{abstract}
The search for innovative ideas and sustainable solutions for urban housing in Southeast Asia as well as other parts of the world should include reexamining and rediscovering traditional urban dwellings such as the shophouse. Based upon the author's observation in many parts of Southeast Asia such as Malaysia, Thailand, Vietnam and Indonesia, new housing for lower income populations in urban areas have tended to be high-rise or walkup multistorey flats with little or no commercial space within the developments. These high-density urban dwelling environments have the usual problems associated with large-scale high-rise housing projects. They are impersonal, monotonous and boring, and they do not allow much room for individual expression, expansion or personalization of the dwelling. In these planned housing schemes, residential and commercial activity is usually separated. In Southeast Asia where mixed-use urban settlements have been the tradition for generations, the separation of residential and commercial activity usually does not work. Strict and constant supervision is required or else open space around housing areas is soon occupied by unauthorized commercial activity. In the older and more traditional sectors of urban settlements in Southeast Asia, commercial and residential activities coexist together usually in the same building-the shophouse. In older sections of Southeast Asian cities, shophouse neighbourhoods, although seemingly crowded, are lively environments that give cities in the region their distinctive character. An analysis of the traditional shophouse of the Malay Peninsula is described here and is proposed as a model for better urban housing environments, which can sustain traditional ways of urban life Southeast Asia and elsewhere.
\end{abstract}

Keywords: Housing, shophouse, southeast Asia, sustaining tradition, urban design.

\section{INTRODUCTION}

The Chinese shophouse of the Malay Peninsula (Fig. 1) is the basic unit of the urban fabric in cities and towns in Malaysia (Fig. 2), Singapore [1], and other countries in the region (Fig. 3). While there are several variations and versions of this typology, the typical Chinese shophouse is basically a long structure two to three stories high with a narrow street frontage. The ground floor is used for commercial purposes such as shops, light industry or service businesses such as laundries, repair shops, etc. Sometimes more than one business may share the ground floor space in a single shophouse. In some variations of shophouses, the residential part is behind the shop. The upper floors are for residential use and may contain living units for several families or individuals who may sometimes share facilities such as kitchens and bathrooms. The ground floor shop front is separated from the street by a covered space known as a verandah. Shophouses are built in rows and share party walls between them. Through this configuration, the covered verandahs become continuous covered walkways along the street. The continuous covered walkway is referred to locally as the verandah way. Rows of shophouses line the streets of oldersections of towns and clearly define the street and the urban block. The uniform rows of shophouses are broken periodically by cross streets or by alleys.

The shophouse contains one or more courtyards, light wells or air wells along its length so as to provide daylight and ventilation to interior spaces (Fig. 4). The roof of the typical shophouse is divided into two or more gabled sections oriented transverse to the long axis of the building [2]. The roofs are supported on the party walls, and since spans are short $(4-7 \mathrm{~m})$, there is often no need for any intermediate vertical supports. The interior space is, therefore, easy to divide up with partitions so as to suit the needs and preferences of the occupants. The heights of facade elements such as the 


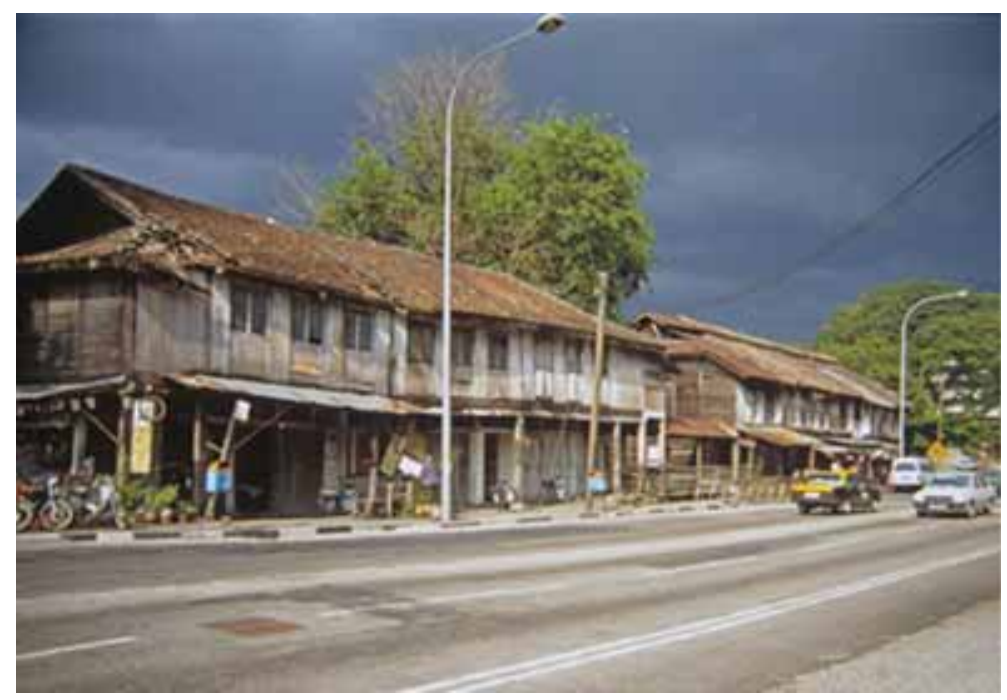

Figure 1: Old wooden shophouses that do not exist anymore, Kuala Lumpur, Malaysia, 1988.

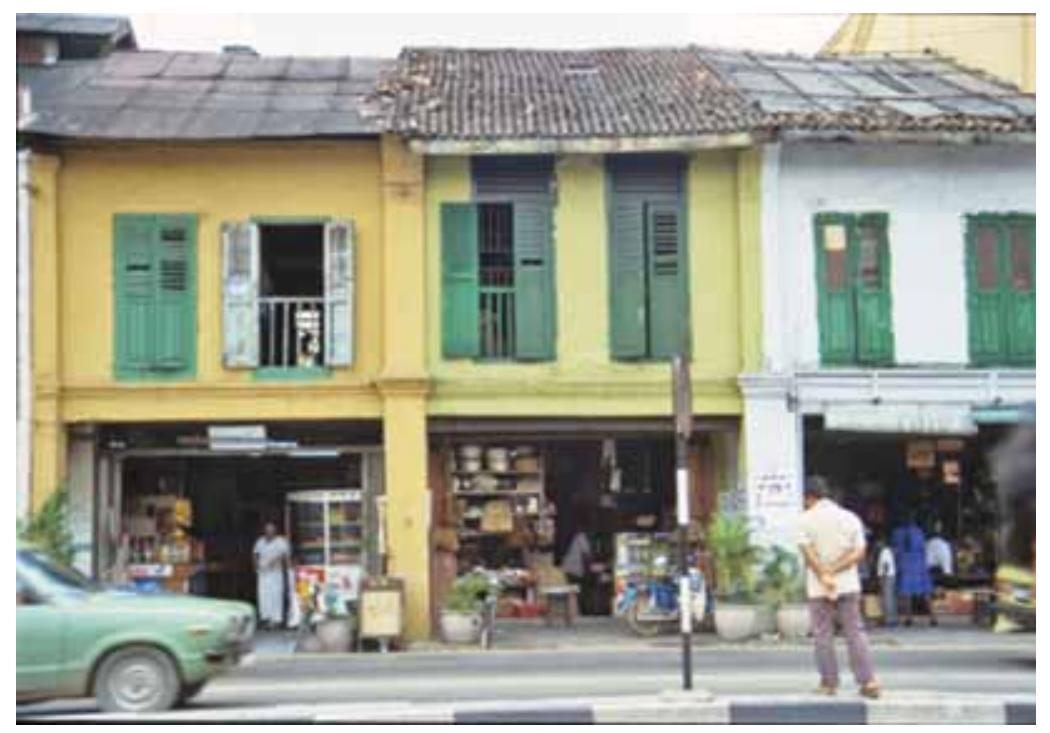

Figure 2: Two-storey shophouses showing the covered verandah way and shuttered floor to ceiling windows that allow light and cross ventilation, in Port Klang, Malaysia, 1987.

cornices, mouldings, window heights, etc., are usually coordinated so as to control visual unity. At the same time, there remains flexibility and scope for individual expression through the use of architectural styles, various types of openings, colours, materials, etc.

The facade that faces the street is usually regarded as the front and is the public side of the building. More recently, the visual unity that was once a characteristic of blocks of shophouses in some parts of Southeast Asia is now altered by upward expansion. In Vietnam, shophouses have been 


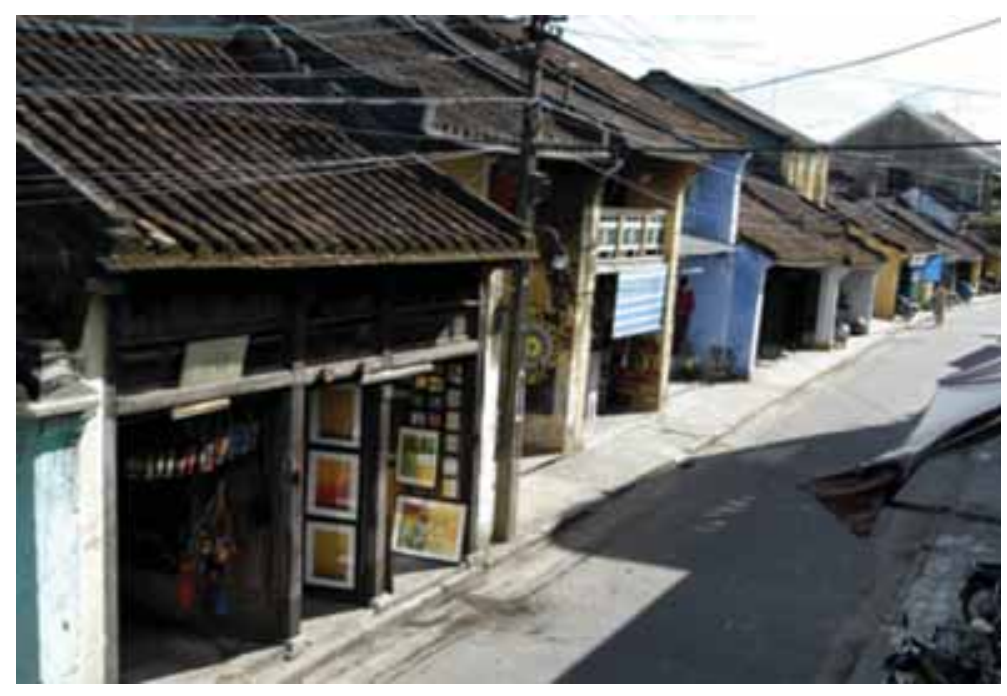

Figure 3: Single-storey shophouses with shop at the front and dwelling in the rear in Hoi An, Vietnam, 2004.

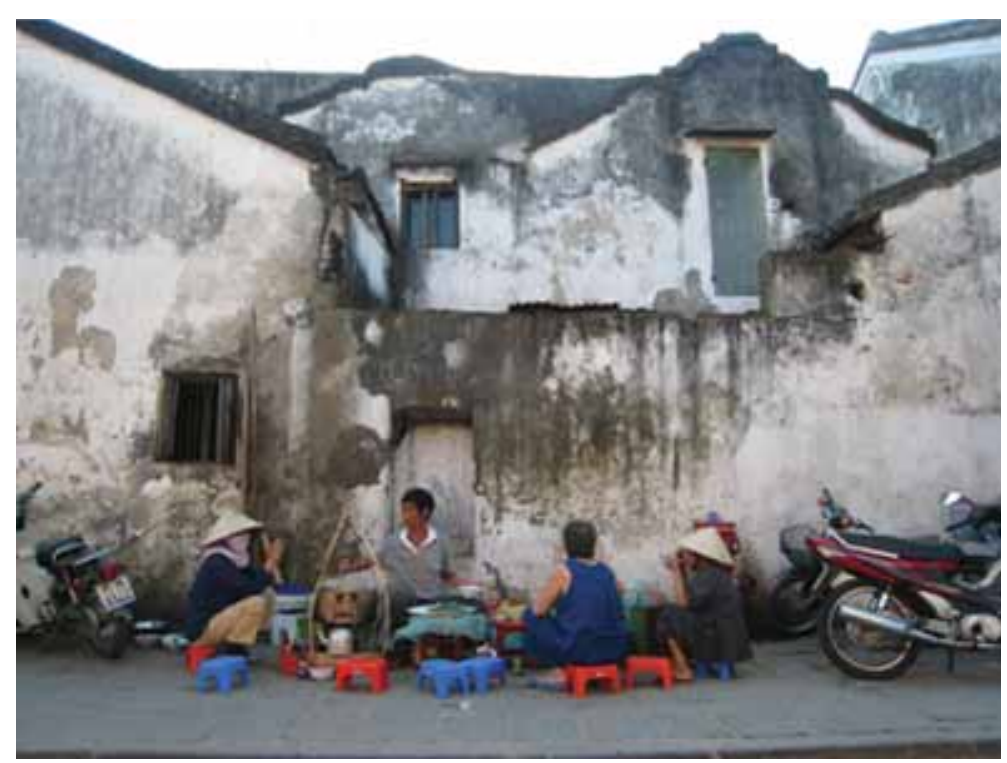

Figure 4: Side view of shophouses showing one of the interior courtyards, Hoi An, Vietnam 2007.

expanded to over seven stories (Fig. 5). This upward expansion of a deep but narrow building raises issues about safety and egress from upper floors. However, because of the rapid pace of change, buildings are built before safety regulations can be put in place. The rear of the building traditionally faces a service alley that is clearly the back of the shophouse. The alley is used for service to the commercial as well as the residential parts of the building. 

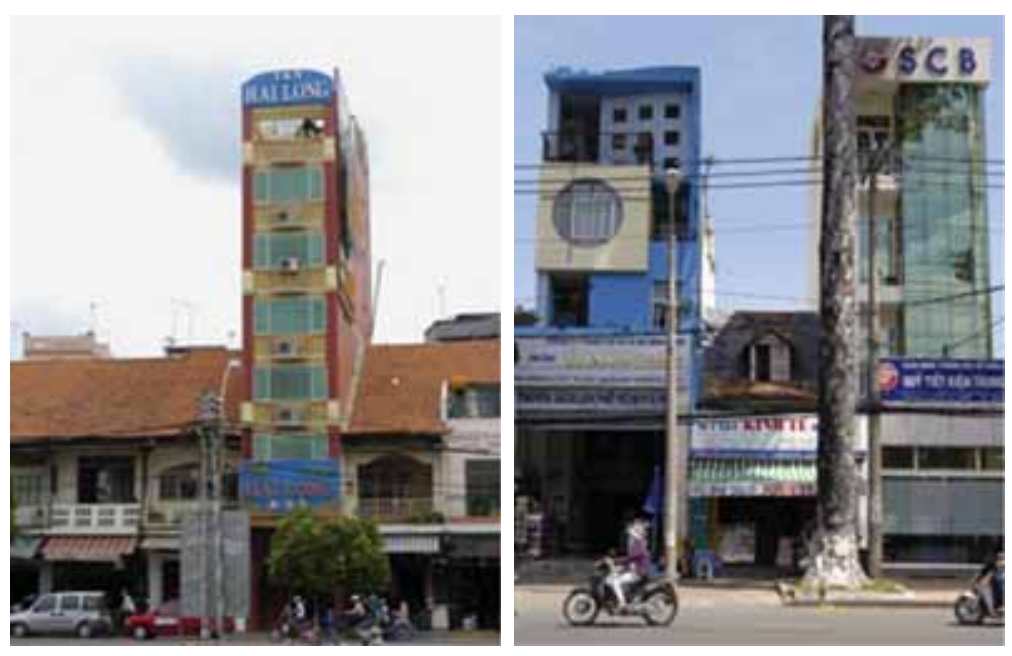

Figure 5: The harmony of the facades in a row of old shophouses is broken by contemporary upward expansion and reflects the changing skyline in Ho Chi Minh City, Vietnam, 2004.

\section{URBAN ATTRIBUTES OF THE SHOPHOUSE}

As an urban dwelling typology, three important characteristics of the Southeast Asian shophouse can be identified. They are:

- Mixed-use urban space.

- Flexibility.

- Pedestrian oriented.

In the following sections, each of these three features is examined and ideas for incorporating them into design schemes of new housing are discussed.

\subsection{Mixed use urban space}

At the present time, when energy needs to be conserved; increasing environmental pollution requires attention; commuting between dwelling and workplace is getting harder because of urban sprawl and in particular, the complex issues of environmental sustainability are major concerns in cities, the shophouse provides a model for mixed-use mid-rise housing developments that can combine and integrate living, working, recreation and community space. In the Southeast Asian city, residential, commercial and workspaces have traditionally existed side-by-side (Fig. 6). The shophouse makes it possible to continue this tradition while also providing more sustainable user and environmentalfriendly urban environments.

In cities in developing countries, it is necessary for small business and commercial opportunities to be located near residential areas because many people do not have private transportation or access to public transportation to travel long distances to commercial areas in the city. Urban development that incorporates the shophouse or that is based upon the aspects of the shophouse that have been described can accommodate these needs. Developments of this type allow the scale of the commercial or business activity to be matched with the needs of communities. Larger businesses as well as small family run enterprises (such as a photocopy shop or beauty parlour) can be accommodated 

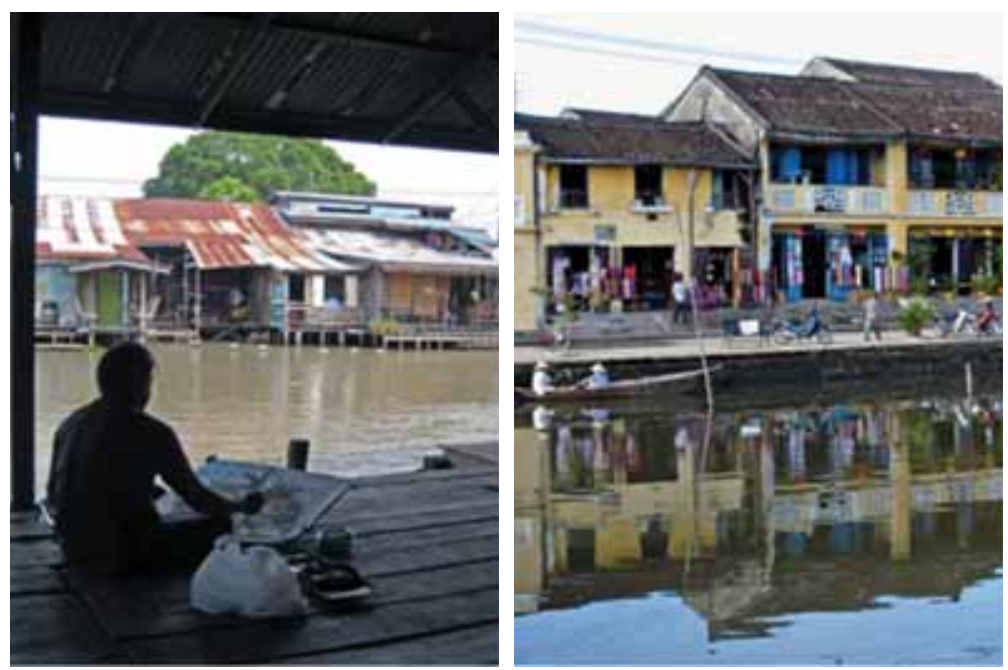

Figure 6: Shophouses along a river outside Bangkok, Thailand and in Hoi An, Vietnam.

sidebyside with small super markets, branch banks or offices. The mixed-use aspect of the shophouse and developments that incorporate its features can reduce the dependence upon the automobile. Residents may not have to travel large distances to work because there can be employment and business opportunities near the home. Mixed-use urban housing modelled after the shophouse can optimize land use without compromising density. If designed cleverly, mixed-use housing based upon the shophouse can facilitate lively environments that can enhance the quality of urban life.

The contemporary trend in Southeast Asia as in many other parts of the world is to separate residential and commercialactivity by locating them in separate zones within neighbourhood developments. This separation doesnot lend itself well to sustaining vibrant urban environments and in particular does not sustaincontinuity of traditional urban life in Southeast Asia. Housing in new residential developmentsin Malaysia where residential and commercial activities are separately located results in monotonous and dull rows of multistoried flats in which public open spaces are poorly integrated with dwellings. These open spaces that read as left over spaces are generally underutilized, sterile and dull. Very often, these underutilized open areas are occupied by street hawkers who move into the area because they see a need for the goods and services that they can offer. Hawkers and vendors view the open unused spaces as opportunities to be as close as possible to potential clients and prospective customers. Soon these spaces degenerate into places that are dirty, crowded, unsanitary and hazardous to health and safety.

In Southeast Asia, street vendors are an essential part of the urban economy (Fig. 7). In lower income housing frequently these vendors are residents themselves. Street vending provides lower income families, and particularly, women, the elderly or the disabled, with economic opportunities near or in the home. In developing countries in Southeast Asia (and in many other parts of the world), it does not take long for unauthorized commercial activity to spring up in and around housing projects. This activity may start with a table or cart that is temporarily placed in a convenient public area such as along a boundary wall or access street. Very soon larger and more permanent structures are built and strips of commercial squatter activity develop and thrive. The covered walkway in shophouses provides sheltered space for street vendors who constitute an essential part of the culture, lifestyle and economy of Southeast Asian cities to provide their services by setting up temporary stalls that are protected from the weather. 


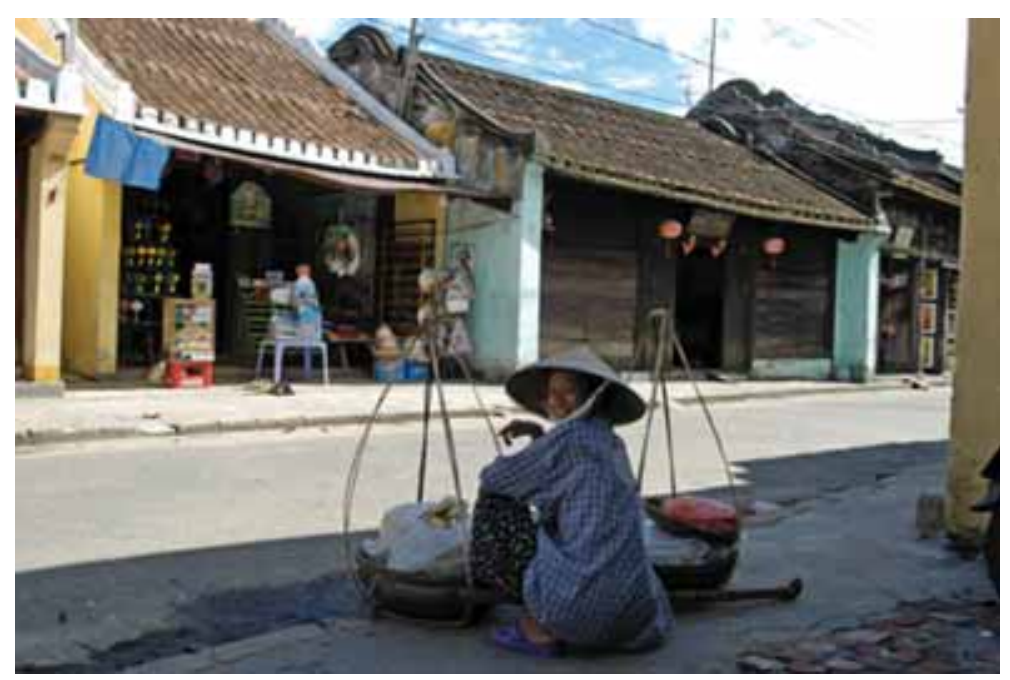

Figure 7: Street vendor and open and shuttered shophouses in Hoi An, Vietnam, 2004.

Multifamily housing can respond to inhabitant needs in a more appropriate manner if designed as mixed-use developments, much like the shophouse, which integrates commercial/workspace with residential space. Through sensitive design, the role of small businesses and street vendors in the economy can be acknowledged and their presence can be accommodated when planning and designing new neighbourhoods. Large-scale housing projects should include a combination of shophouses and other house types so as to address requirements of density while also creating better urban dwelling environments.

\section{FLEXIBILITY}

Next to affordability, flexibility in design is essential for successful housing. Flexibility should be designed into housing so that occupants can construct, modify, change or expand the dwelling unit so as to suit present and future functional, economic and cultural needs of individuals or families. The simple structural system and layout of the shophouse can be applied to low to mid rise high-density housing so as to achieve maximum flexibility, in the arrangement of internal spaces, in initial construction and also in the incremental expansion of the building over a period of time as the occupants' needs change. The concept of corehousing may be applied to shophouse developments. The core could be the outer shell of the building or the party walls, along with certain amenities such as kitchens, and toilets. If prefabrication of building components is a viable option, the components can be designed so as to facilitate a self-build approach to the construction or expansion of the house. Creative and intelligent design can allow individual units to be added to (vertically or horizontally) or be modified over time. To regulate construction and to ensure safety, guidelines and restrictions may be developed and owners may be provided with access to technical or professional advice.

Flexibility also includes the ability to personalize one's dwelling. In the traditional shophouse, flexibility in the use of architectural styles or in the application of personal taste is made possible within the framework of simple guidelines. These guidelines allow variety, yet maintain visual unity and coherence. The result of this flexibility is variety and richness in the built environment. In mass housing developments, identity is compromised because of uniformity and monotonous repetition. 


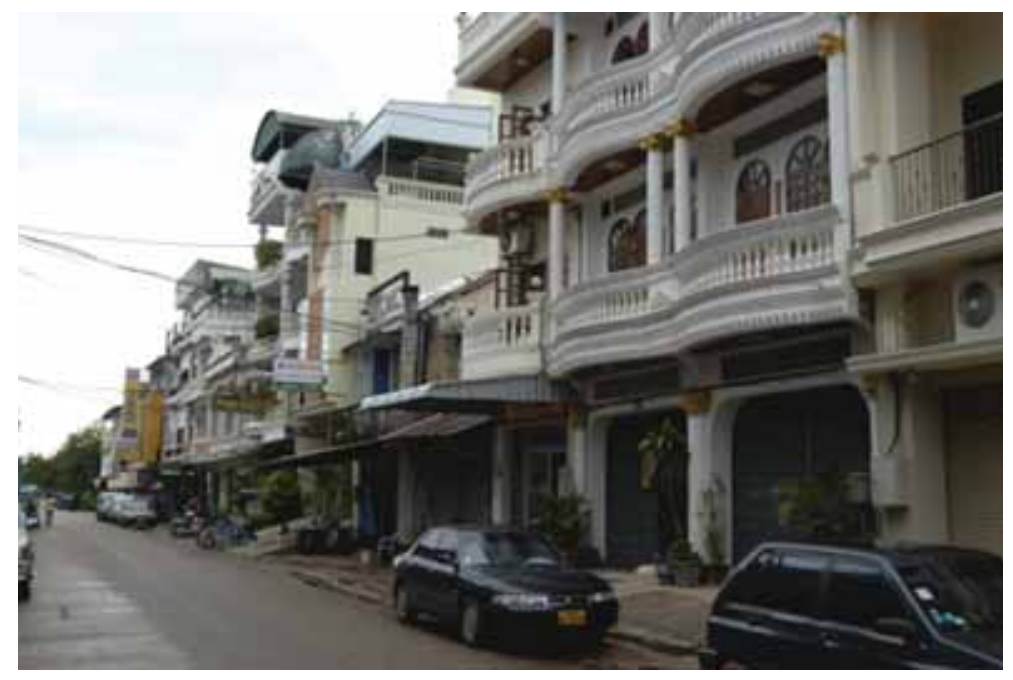

Figure 8: New shophouses in Vientaine reflect current tastes of owners in the applied ornamentation of their facades, 2007.

Low-rise, high-density shophouses can be designed to keep construction costs low, but at the same time allow architectural expression of cultural, regional and personal preferences (Fig. 8).

\section{PEDESTRIAN-FRIENDLY URBAN ARCHITECTURE}

In the context of the tropical Southeast Asian city, the covered verandah way (walkway) of the shophouse provides pedestrians protection from sun and rain. This walkway is a multifunctional space. It acts as a covered sidewalk for pedestrian circulation while also providing sheltered space for street vendors, as well as space for people, especially the elderly, to socialize. Urban environments that are friendly to pedestrians should provide shelter from the weather. Pedestrian-oriented spaces such as the covered verandah way can encourage more people to walk or use public transportation rather than drive private motor vehicles. Reduction in the use or number of motor vehicles will reduce environmental pollution as well as fuel consumption and decrease the need for more parking space and wider streets. The covered walkway or verandah way can be integrated with plazas and courtyards so as to create pedestrian-oriented streets [3]. The walkway may not be restricted to the ground level alone but may also be incorporated above or below ground level so as to allow pedestrian connections across major streets or between groups of buildings. These covered walkways can function in a similar manner to the sky bridges and subways that connect buildings in some North American cities.

Pedestrian comfort can be further enhanced by integrating trees and other plant materials along the street and in plazas and community spaces so as to provide additional shade as well as separation from vehicles. The traditional shophouse has a public front along the street, which is usually busy, noisy and always lively. The rear of the shophouse along the service alley is generally quieter but less attractive. The alley is used for storage of trash containers, storage of street vendor stalls when not in use, parking of automobiles, etc.

Using the shophouse model, mixed-use housing developments could use the street and the alley as a means of separating public (commercial) activity from semi-public (residential or community) 
activity. In doing so, the needs of children and the elderly, as well as the needs for residential and commercial parking of automobiles could be met in an appropriate and safer manner. Alternatively, residential streets could alternate with commercial streets and blocks of shophouses could be clustered around residential courts or commercial plazas. Pedestrian connections or linkages between these courts and plazas could be provided.

\section{DISCUSSION AND CONCLUSION}

Howard Davis in his book, 'Living Over the Store: Architecture and Local Urban Life' [4], points out that the shop/house as an archetype has not received much attention from scholars, and less so by practitioners of urban development. He notes that since the beginning of the twentieth century urban designers and city zoning agencies have favoured buildings with single functions and have prevented the integrated way of life afforded by working and living in the same building. In Southeast Asia, the shophouse was a place that brought the activities of dwelling and commerce together and also served as a pedestrian-friendly building suitable for urban living in the tropics. Via its covered verandah, people were able to walk through the city protected from rain and sun while also able to shop, stop for a drink, meet friends or get their shoes polished. While the shophouse offers a model for integrated urban living by placing dwelling and work or commerce in the same building, it is also highly flexible and adaptable to change. In the latter part of the twentieth century, the new urbanism has advocated pedestrian-friendly communities. The shophouse as building type can help achieve these goals (Figs 9 \& 10).

Southeast Asian shophouses accommodate and allow the coexistence of various types of people, each with their own identity as well as various kinds of work spaces and retail businesses. Flexibility in adding to or modifying space within a traditional shophouse makes it suitable as a sustainable building type that can adapt and accommodate change as family or community needs change. If shophouses are designed and structured in a manner similar to the traditional low to mid rise structures, inhabitants would have greater control in the production and maintenance of the building allowing more room for accommodating individual needs and cultural expression. They can be built with local materials and can employ local craftsmen. The physical and technical attributes of shophouse construction allow for ease in carrying out modification thus facilitating continuity in urban environments while also accommodating change. As an urban building type, the shophouse increases

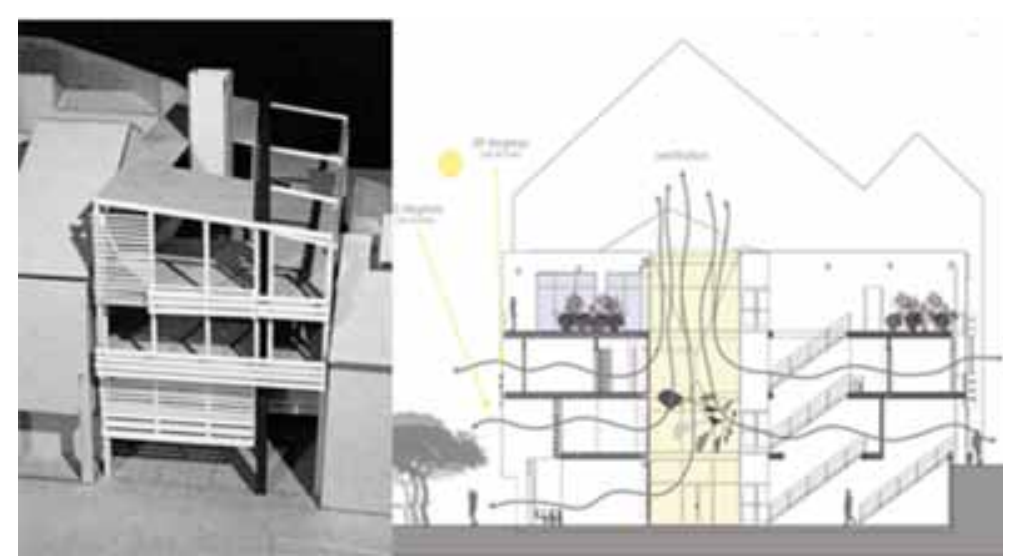

Figure 9: Reinterpreting the shophouse in Singapore (Student Project B. Avalos, Texas Tech University 2011). 


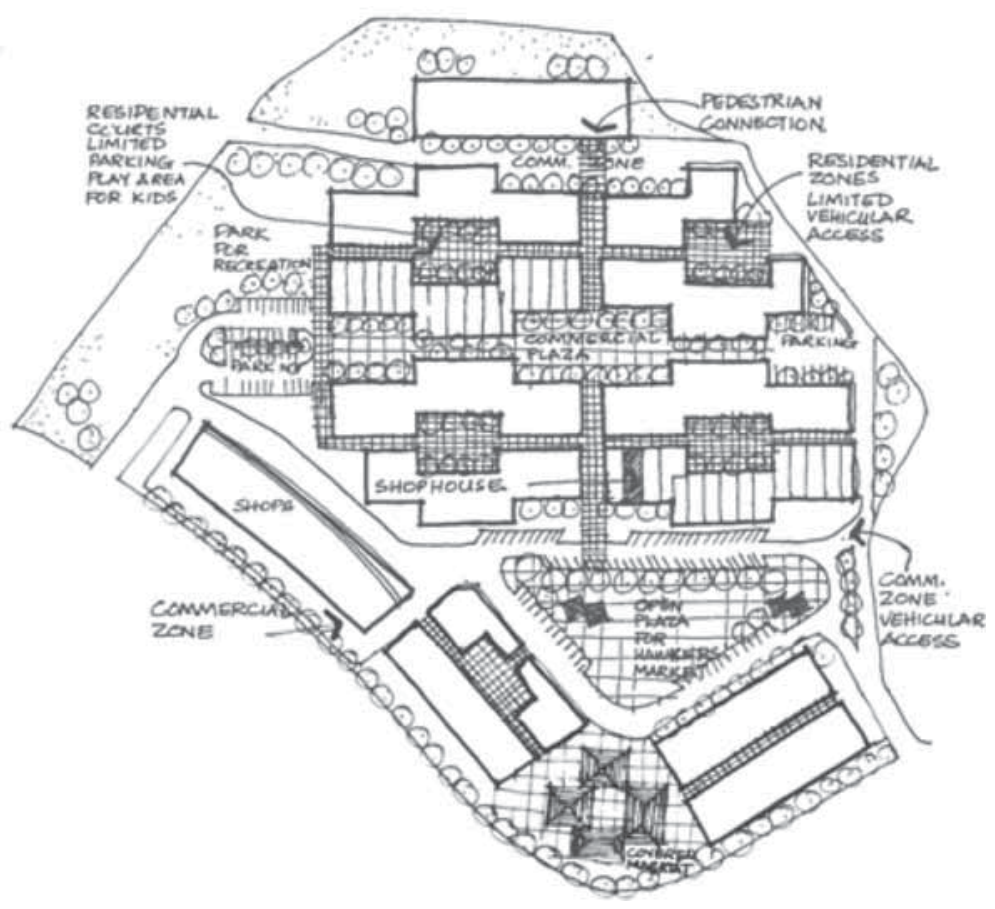

Figure 10: Student design proposal integrating shophouses with multifamily housing and other uses, Kuala Lumpur, Malaysia (G. Mayorga, Texas Tech University).

and facilitates what is referred to by Jane Jacobs as regeneration of dead or decaying urban areas [5]. From an environmental point of view, the presence of one or more courtyards that are essential for light and ventilation in long narrow shophouses provides opportunities for small green spaces that are privately maintained but which collectively contribute to the greening of cities and enhance the health and environmental quality of urban communities.

Presently, there has been a revival of the Southeast Asian shophouse as a commodity for tourist consumption (Fig. 11). During the past two decades or so, in many cities in the region, such as, Singapore, Kuala Lumpur, Bangkok, Hanoi, Phnom Phen, Vientiane, Hoi An and other places existing shophouses have been restored and renovated or new ones have been built as part of urban heritage preservation programmes to attract tourists seeking an experience of days now gone.

In Malaysia, as well as other countries in Southeast Asia, shophouses also continue to be built so as to provide housing in new towns and expanding older cities. Unfortunately, unlike the traditional shophouses, these new designs lack the flexibility for personal expression. They respond poorly to climate and are insensitive to the needs of the pedestrian. These new shophouse developments are designed as mega blocks rather than rows of connected individual buildings. They are examples of architectural designs that imitate the traditional mixed-use urban dwelling environments, without understanding the essential characteristics of the traditional building type, namely the shophouse.

Housing, particularly for lower income populations, has come to be viewed as synonymous with monotony and segregation (Fig. 12). Multifamily housing based upon the attributes of the shophouse could be a viable means of providing better and more environmental friendly urban dwelling 


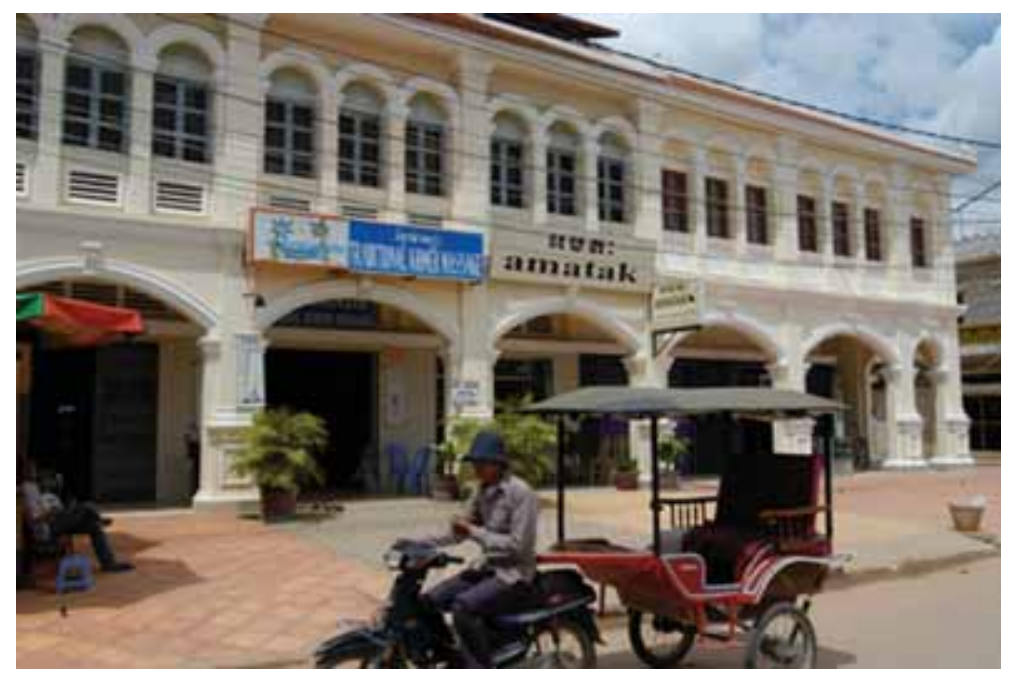

Figure 11: Colonial revival facades of new shophouses in Phnom Penh, Cambodia, 2004.

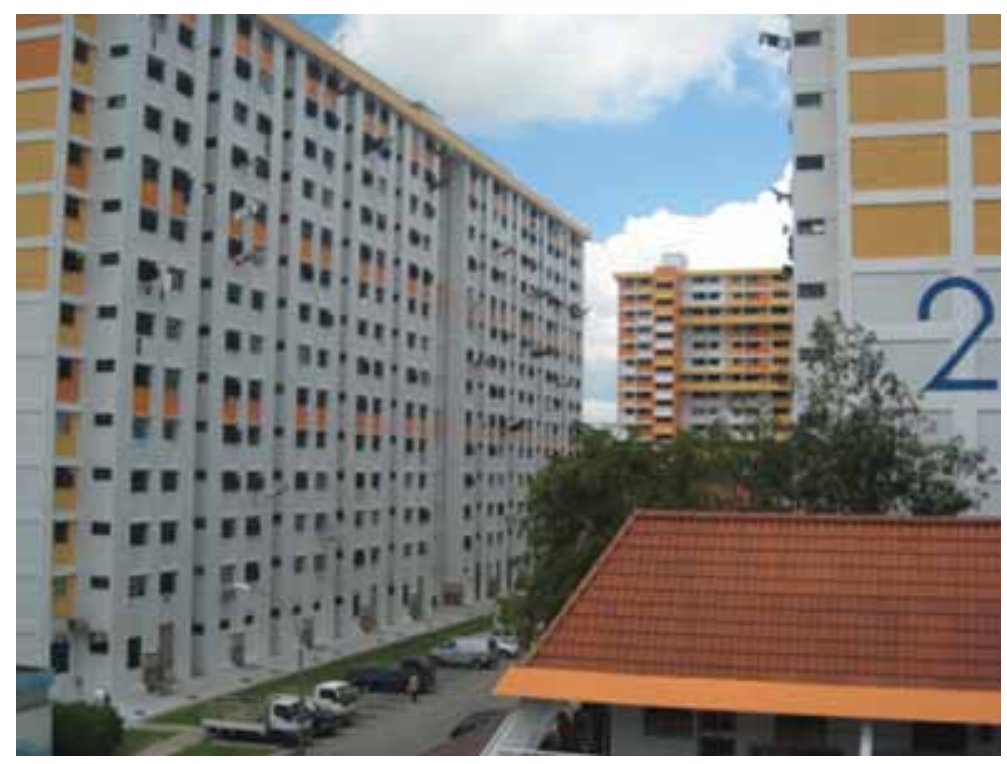

Figure 12: Multifamily housing block, Singapore early 1980s.

environments for this group of people. By integrating places for work, living and recreation into small manageable buildings, shophouse developments may be a smart way to address urban residential environments in tropical cities in Southeast Asia and elsewhere. Success in doing so requires careful analysis and understanding of the architectural features and planning concepts of this traditional urban house form. When the lessons learned from traditional architecture such as the shophouse are architecturally integrated with innovative technologies such as solar energy systems, wind power, waste water recycling, rain water harvesting, etc., better urban dwelling environments, 
healthier communities and walkable cities can be the result. If cities embody some of man's greatest achievements [6], then the shophouse as a multi-use urban building type can be included in those achievements. Re-interpretations of the traditional Southeast Asian shophouse and intelligent adaptations of its attributes offer hope for better socially, culturally, environmental and economically sustainable urban communities and housing.

\section{NOTE}

Material for this document is based upon the author's field research and observation over a period of more than two decades studying and documenting traditional architecture in Malaysia, Singapore, Indonesia, Thailand, Vietnam, Laos and Cambodia.

All photographs and drawings are by the author unless specified otherwise.

\section{REFERENCES}

[1] For more details about shophouses see: Kohl, D.G., Chinese Architecture in the Straits Settlements and Western Malaya: Temples, Kongsis and Houses, Heinemann Asia: Kuala Lumpur, Ch 6, p. 172-186, 1984. Knapp, Ronald, Chinese Houses of Southeast Asia: The Eclectic Architecture of Sojourners and Settlers, Tuttle Publishing: North Clarendon, p. 12-39, 2010.

[2] Chen Voon Fee, Encyclopedia of Malaysia Architecture, 5, Archipelago Press: Singapore, p. 90-91, 1999.

[3] Yeang, K., The Tropical Verandah City-Some Urban Design Ideas for Kuala Lumpur, Asia Publications: Kuala Lumpur, Malaysia, p. 17-35, 1986.

[4] Davis, H., Living Over the Store: Architecture and Local Urban Life, Routledge: UK, p. 52012.

[5] Jacobs, J., The Death and Life of Great American Cities, Random House: USA, p. 143-177 2002.

[6] Bacon, E., Design of Cities, Revised edn., Penguin Books: USA, p. 13, 1974. 